\title{
RESTORING A DEGRADED COASTAL WETLAND IN THE CITY OF CAROLINA, PUERTO RICO: A CASE STUDY
}

\author{
JAVIER VÉLEZ AROCHO ${ }^{1}$, JORGE COLL RIVERA², EDGAR O. VÁZQUEZ PLASS ${ }^{1}$, \\ GABRIEL RODRÍGUEZ ROJAS ${ }^{1} \&$ ALEJANDRO RODRÍGUEZ ROJAS $^{1}$ \\ ${ }^{1}$ EcoStahlia Consultores Ambientales, LLC, Puerto Rico \\ ${ }^{2}$ Coll Rivera Environmental, Puerto Rico
}

\begin{abstract}
A wetland restoration project was proposed in the City of Carolina, Puerto Rico as a compensatory measure for the environmental impacts associated with the construction of the Children Museum that resulted in the filling of 3 acres of coastal wetlands. Restoring marginal coastal lands into a productive wetland area involves returning the selected area to its original state or to improve existing conditions to support new populations of plants and organisms. This approach required the conversion of uplands and shallow, intermittently submerged lands into forested wetlands. Applying the desired techniques was challenging as many of the available literature is focused on creating herbaceous wetlands. The restoration and mitigation activities involved the establishment of appropriate natural hydrologic conditions followed by the reestablishment of the plant community. To reduce potential failure of the functionality of the restoration parcel, the design involved measures to improve the hydrology, and the concept of self-design in which native mangrove propagules and seeds were reintroduced in the ecosystem to reestablish these plants populations. An open water channel was designed and constructed to allow tidal flow of water into the restored area. The design also included the use of specific native trees and plant species with higher colonization success in wetland conditions. An $85 \%$ survival rate was established in order to consider the proposed project as a successful one. Also, variables including tree growth, and use of the restored habitat by wildlife have been recorded over a 4-year period in order to analyze the results of the mitigation project. Impacts from weather conditions including droughts and hurricanes were also recorded to assess success overtime.
\end{abstract}

Keywords: wetlands restoration, ecosystems management, coastal natural resources, Puerto Rico.

\section{INTRODUCTION}

According to Mitsch and Gosselink, wetlands have been described as "ecological supermarkets" because of the extensive food chain and rich biodiversity they support [1]. These ecosystems play a major role in the landscape by providing unique habitats for a wide variety of flora, fauna, and microbial species from both terrestrial and aquatic systems. More recently, wetlands are being described as important water-quality enhancement ecosystems, flood mitigation systems, carbon sinks, and climate stabilizers on a global scale. Coastal wetlands form a critical ecotone at the boundary between freshwater and marine environments and thus provide essential habitats and nutrients to both systems. They are valued by society because they stabilize the coastline and provide protection from storm surge and flooding, improve water quality by filtering nutrients, sequester carbon, and provide aesthetic, recreational and tourism value. This value is considered as a key element in the efforts to restore coastal wetlands around the world [1].

In 2001 the Autonomous Municipality of Carolina (northern Puerto Rico), built the Children Museum (CM) as part of a capital infrastructure investment program (Fig. 1). The building is located about $2 \mathrm{~km}$ southeast of the Luis Munoz Marín International Airport. The construction site selected was originally an herbaceous wetland and mangrove forest that has been urbanized since the 1960s. This project was authorized by the United States Army Corps of Engineers (USACE) under Section 404 of the US Clean Water Act [2]. Construction of the Project required the discharge of fill material into 3 acres of herbaceous wetlands. This 
discharge was authorized under permit SAJ-2001-3999 (VG), issued by the USACE. Wetland restoration involves returning a wetland to its original or previous wetland state, whereas wetland creation involves conversion of uplands or shallow open-water systems to vegetated wetlands. Wetland restoration and creation can be used to replace degraded or disturbed habitat, for coastal restoration, and for restoration of mined peat lands. Generally, wetland restoration and creation first involve establishment or re-establishment of appropriate natural hydrologic conditions, followed by establishment of the appropriate plant communities. Although many of these created and restored wetlands have become functional, there have been some cases of failure usually due to a lack of proper hydrology. Having ground water inflow is often desired because this offers a more predictable and less seasonal water source. Surface flooding by rivers gives wetlands a seasonal pattern of flooding, but such wetlands can be dry for extended periods of time during the dry season. Depending on surface, runoff and flow from low-ordered streams can be the least predictable. Often wetlands developed under these conditions are isolated pools and potential mosquito havens for a good part of the growing season; their design should be carefully considered. It is generally considered optimal to build wetlands where they used to be and where the hydrology source is still in place for the wetland to survive [3].

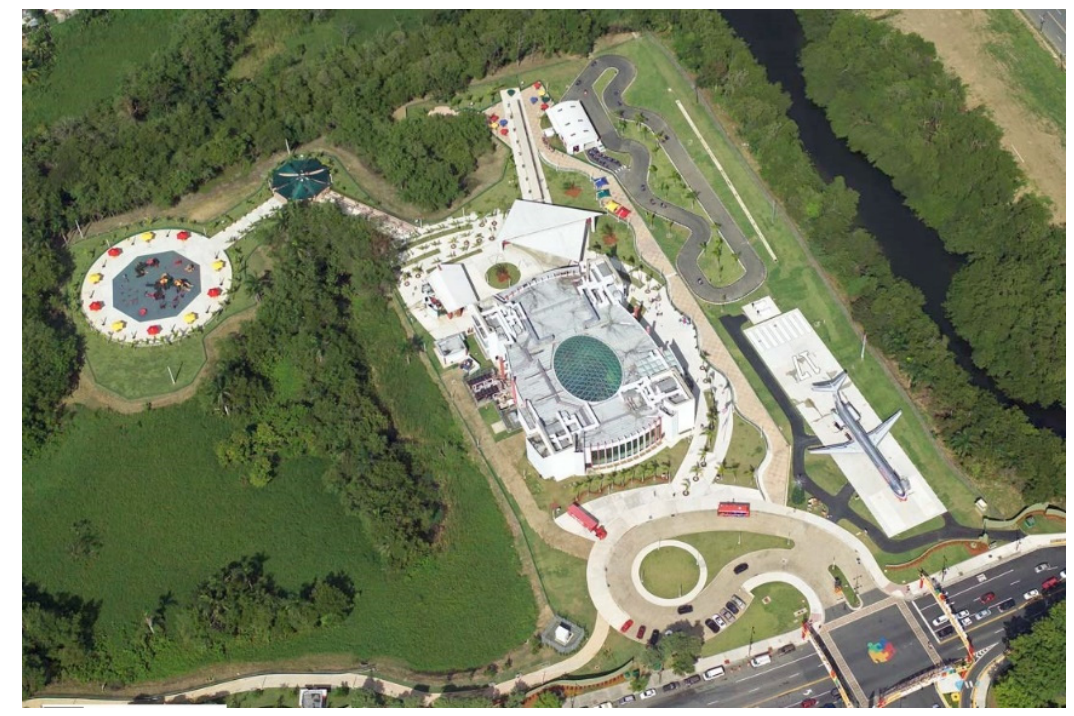

Figure 1: Aerial view of the Children Museum - Courtesy of the City of Carolina.

The Council on Environmental Quality (CEQ), overseeing the National Environmental Policy Act (with which the USACE must comply) has defined mitigation in its regulations at 40 CFR 1508.20 to include: avoiding impacts, minimizing impacts, rectifying impacts, reducing impacts over time, and compensating for impacts. Department of the Army permits under the Clean Water Act Section 404 must comply with the 404(b)(1) Guidelines (40 CFR 230), which establish the environmental criteria by which activities are permitted under Section 404, including methods to reduce project impacts on the aquatic environment. This procedure starts with avoiding impacts to aquatic resources to the extent practicable, minimizing unavoidable impacts, and finally, compensating for any remaining unavoidable impacts to aquatic resources. Note that the Mitigation Rule mention the need for mitigation 
of impacts to all aquatic resources, not just wetlands. Both the USACE and the U.S. Environmental Protection Agency (EPA) have a national goal of no overall net loss of aquatic resource acreage, as explained in the agencies' 1990 Memorandum of Understanding and the Mitigation Rule.

In this project the impacted aquatic resources were herbaceous wetlands and remnants of a mangrove forest. According to the National Wetland Inventory (NWI) the CM site wetlands were classified as estuarine, intertidal, emergent, persistent, irregularly exposed (E2EM1M) [3]. In 2003, an assessment and analysis of the CM site aquatic resources functions and values were performed to determine which ecological functions provided by the wetland to be impacted will be lost and thus needed to be compensated. The methodology used for this analysis was the Wetland Rapid Assessment Procedure (WRAP). This procedure provides an accurate and consistent evaluation of the ecological value of the wetlands to be impacted within the Project area. The WRAP methodology was developed by the South Florida Water Management District (SFWMD) to assist in the regulatory evaluation of mitigation sites [4] (SFWMD, 1999). A standardized WRAP rating index was used to provide an accurate and consistent evaluation of the existing wetland at the CM site. It is important to mention that historical changes in land use within and around the Project area have significantly disturbed the natural landscape of existing wetlands. These changes were considered during the wetland assessment.

The WRAP rating index combines numerical scores for six ecological and anthropogenic variables for each wetland. Each variable score varies from 0 to 3 . The final WRAP score is the sum of all variable scores divided by the maximum possible score, presented in a range from 0 to 1 . These variables are: wildlife utilization, wetland overstory/shrub canopy, wetland ground cover, habitat support/buffer, field hydrology, and water quality input and treatment. The results of this assessment are summarized as follows:

- Wetlands within the CM project site showed significant impact due to previous (agricultural) and current (urbanization) land use.

- Two types of wetlands were assessed within the project to evaluate the ecological functions these ecosystems provide. The wetlands were divided into herbaceous and mangrove wetland. Overall WRAP score of the mangrove wetland area had an overall WRAP score of 0.69 and the herbaceous wetlands showed the lowest WRAP with a 0.30 score. Both wetlands exhibited low wildlife utilization, and relative high proportion of invasive and early-succession plant species. Areas of re-establishment and enhancement, as well as preservation areas were also assessed.

A higher WRAP score represents a better quality of wetland values and functions, while a lower score reflects the degree of habitat degradation the wetland has suffered from human-induced changes which have had an impact on the ecological functions they provide. The WRAP procedure is neither an evaluation of their "ecological importance", nor a method to compare between wetland communities, as stated in the WRAP procedure itself. Results of this procedure provide an index of the impact that these wetlands have undergone, which is exhibited through their actual attributes including overgrowth of invasive grass species, and low species richness of tree species common in other wetlands of the island.

Here we present a case study of wetland habitat restoration in a subtropical Caribbean island in which a degraded wetland previously used as a dump site for fill material is restored into a functional community by restoring its vegetation land cover, increasing habitat quality for wildlife, mitigating the negative effects of decades of anthropogenic disturbance and improving site aesthetics. 


\section{METHODOLOGY}

\subsection{Study site}

During the planning phase, a property located north of the CM was identified with hydraulic and hydrological connectivity to a nearby stream, named Canal Blasina. This property was located approximately $50 \mathrm{~m}$ from both, the main channel of Canal Blasina, and an overflow channel that comes from a smaller lagoon located southwest of the CM site (Fig. 2). Measurements of surface water elevation (meters above mean sea level), conductivity $(\mu \mathrm{S} / \mathrm{cm}), \mathrm{pH}$ (units), and temperature $\left({ }^{\circ} \mathrm{C}\right)$ were taken to ensure that the selected land can become a successful wetland restoration project. Surveying of the three parcels (mitigation sites $\mathrm{A}, \mathrm{B}$ and $\mathrm{C}$ ) were completed and existing ground elevations within the three mitigation areas were determined. The survey data showed that elevations vary between 0.2 and $3 \mathrm{~m}$ above mean sea level (AMSL). Once the surveying was completed and all required permits were obtained, the proposed mitigation project started with the construction of an open water canal from uplands. Using heavy equipment (excavator), a $2 \mathrm{~m}$ wide and $100 \mathrm{~m}$ long canal was built to connect the forested wetlands of the enhancement areas to a secondary canal, which at the same time connects an open water pond with the Canal Blasina outside the mitigation site. This canal allowed the influx of water into the existing degraded wetland (Fig. 3). Vegetation within the project site consists of two plant communities: herbaceous and mangrove wetlands. This classification is based on the dominant vegetation present at the community when the WRAP procedure was performed.

The proposed compensatory mitigation sites included tree wetland areas (Fig. 2). Mitigation Area A consists in the establishment of a canal approximately 0.045 acres $\left(184.1 \mathrm{~m}^{2}\right)$ that connects approximately 1.8 acres $\left(7367.7 \mathrm{~m}^{2}\right)$ of forested wetlands to main source of water, Canal Blasina. This forested wetland was established by enhancing an existing degraded herbaceous wetland. In addition, approximately 0.2 acres $\left(929.5 \mathrm{~m}^{2}\right)$ of forested wetland (mostly red mangrove) was created along the slopes of the canal to be constructed. A forested upland buffer zone of approximately 0.46 acres $\left(1845.6 \mathrm{~m}^{2}\right)$ was established along the eastern perimeter of Mitigation Area A. Total Mitigation Area A including mitigation works ( 2.5 acres) and existing forested wetlands were 5 acres.

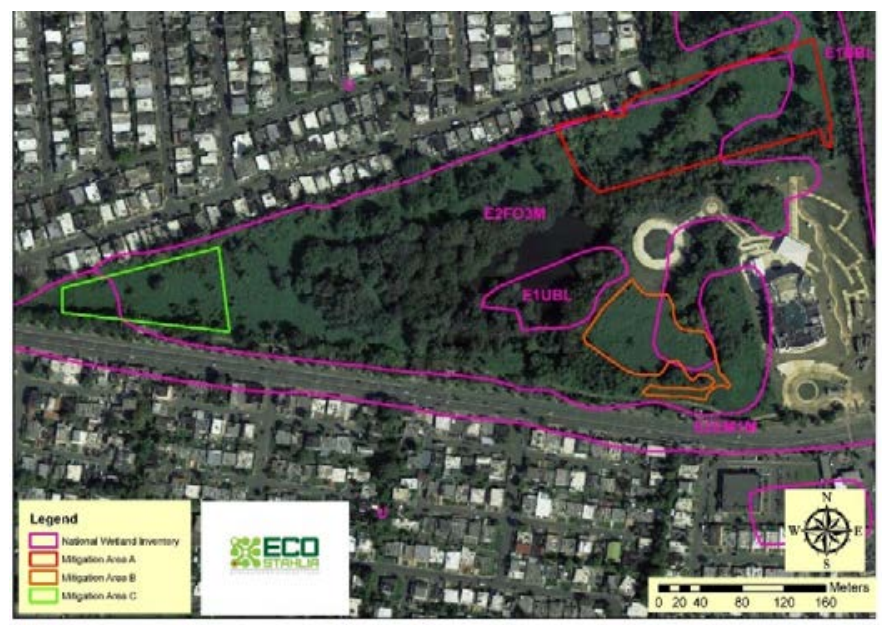

Figure 2: Aerial photo of CM wetland Mitigation Areas. 
Mitigation Area B consisted of the enhancement of another degraded herbaceous wetland located west of the Children Museum. Total area of Mitigation Area B is approximately 2 acres $\left(8025 \mathrm{~m}^{2}\right)$ and construction in the site begun in 2019. Mitigation Area C consisted in the enhancement of a degraded herbaceous wetland located west of Mitigation Area A. Total area of Mitigation Area $C$ is approximately 2 acres $\left(8085.6 \mathrm{~m}^{2}\right)$ and wetland enhancement activities in the site begun in 2019. The combined area of the three compensatory mitigation sites was 9 acres. A conservation easement of the three mitigation sites (A, B and C) was created to ensure its protection.

The Compensatory Mitigation Plan (CMP) [5] was prepared by EcoStahlia Consultores Ambientales, LLC and Coll Rivera Environmental, as part of the requirements of the USACE for a Section 404 Clean Water Act Permit. It follows the Regulatory Guidance Letter No. 02-02 (Guidance on Compensatory Mitigation Projects for Aquatic Resource Impacts Under the Corps Regulatory Program Pursuant to Section 404 of the Clean Water Act and Section 10 of the Rivers and Harbors Act of 1899), the Final Rule of Compensatory Mitigation for Losses of Aquatic Resources 40 CFR Part 230 (specifically part 332.4 (c)), and the Regulatory Guidance Letter No. 08-03 (Minimum monitoring requirements for compensatory mitigation projects involving the restoration, establishment, and/or enhancement of aquatic resources) [6].

\subsection{Design of compensatory mitigation areas}

According to the Regulatory Guidance Letter for the Establishment and Maintenance of Compensatory Mitigation Projects (RGL 02-2 of December 24, 2002), there are four types of wetland mitigation method; establishment (or creation), restoration (re-establishment or rehabilitation), enhancement, and protection or maintenance (preservation) [7]. Some of these wetland mitigation methods could be more successful than the others, depending on the hydrological, chemical and biological conditions around and within the mitigation area. Hydrological conditions, including variability in water levels and water flow, are the primary forces influencing wetland development, structure, functioning, and persistence. The main goals of a compensatory wetland mitigation project are to obtain a no net loss of national wetlands acreage and to avoid or minimize the impacts on the ecological functions and values that wetlands provide on a geographic region. Although wetland establishment or creation have been widely used as a compensatory method to avoid or minimize the loss of wetlands functions and values, the no net loss of wetland has not been met for wetland functions. A tendency to restore former wetlands or enhance existing ones has proved to be more successful, given that wetland hydrology, soils and hydrophytic vegetation is usually present or is close to the mitigation project area. One of the most important reasons for the lack of success on the establishment of some new wetland projects is that the necessary conditions for its development are not close to the mitigation site [7].

The existing ground elevations within the Compensatory Mitigation Sites (CMS) vary between 0.2 and $3 \mathrm{~m}$ above mean sea level. The most important hydrographic feature in the CMS was the existing canal that connected an open water area (outside the CMS) with the Canal Blasina to the east. This canal, which is adjacent to the south side of the CMS, was considered the permanent hydrology source through the creation of an open water canal connecting both areas. The substrate of the canals and open water area are unconsolidated organic material. The U.S. Department of Agriculture's Natural Resources Conservation Service classified soils within the CMS site as "Made Land" (Md). Made land soils consisted of areas where the soil profile has been covered or destroyed by earthmoving operations and generally have been graded for engineering purposes. [8]. 


\subsection{Establishment of an open water canal from uplands (E1UBL)}

This compensation method provided open water functions and values to the forested wetland creation and wetland enhancement areas; the latter being enhanced also to forested wetlands. Using heavy equipment (excavator), a $2 \mathrm{~m}$ wide and $100 \mathrm{~m}$ long canal was dig up to connect the forested wetlands of the enhancement areas to a secondary canal that connects to an open water pond of Canal Blasina outside the mitigation site. This structure allowed the influx of water into the existing degraded wetland. The constructed canal has an area of approximately 0.045 acres $\left(184.1 \mathrm{~m}^{2}\right)$ and was constructed mostly on uplands (Fig. 3). The canal connects the new reforested and enhanced upland and wetland areas to a secondary canal that discharges into the Canal Blasina. The bottom of the canal had an elevation of $-0.2 \mathrm{~m}$ below mean sea level; therefore, it was permanently inundated. Wetland tree species like Red mangrove (Rhizophora mangle), White mangrove (Laguncularia racemosa) and Black mangrove (Avicennia germinans) were planted along the slopes of the canal. This method was carried out at Mitigation Area A.
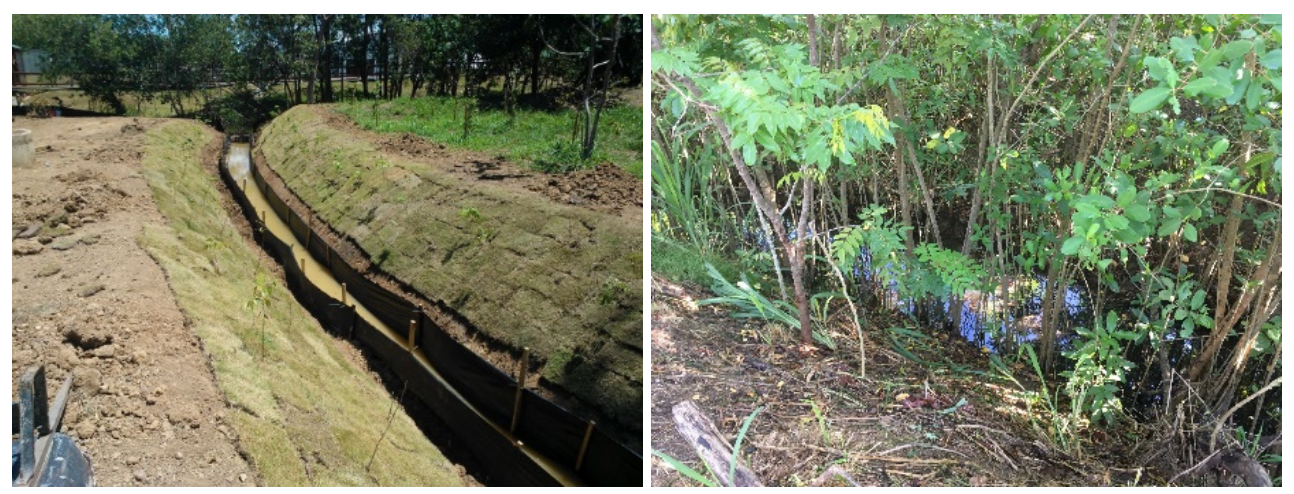

Figure 3: Before and after of the open water canal connecting Mitigation Area A with secondary freshwater canal.

\subsection{Establishment of forested wetlands from uplands (E2FO3M)}

Approximately 0.2 acres $\left(929.5 \mathrm{~m}^{2}\right)$ of degraded herbaceous uplands were converted to forested wetlands by planting native wetland tree species (Table 1). The species selected for reforestation were in good condition and adapted to the hydrological conditions (i.e., low salinity) found at the planting site. The upland of Mitigation Area A was connected to its main water source (Canal Blasina) by the constructed canal described above. This area was planted with transitional and wetland species, such as Cabbage bark (Andira inermis), Alexandrian laurel (Calophyllum antillanum), Maga tree (Thespesia grandiflora), Cayur (Annona glabra), and Bloodwood (Pterocarpus officinalis). A total of 202 trees were planted at $4 \mathrm{~m}$ from each other allowing enough space for future growth. Within the parcel three permanent circular sampling plots of $100 \mathrm{~m}^{2}$ each were established. On each plot, height and diameter at breast height (DBH) of trees were measured. If tree height was less than $2 \mathrm{~m}$, a diameter measure of tree stem was taken at $10 \mathrm{~cm}$ above soil surface. This method gave an additional parameter to assess before those trees grow higher than $2 \mathrm{~m}$. In addition, percent cover of herbaceous vegetation was estimated on each sampling plot and nuisance or undesirable species were identified and their percent cover was also estimated. 
Table 1: List of plant species and number of trees planted at the compensatory mitigation sites. (Source: CMPARI: Compensatory Mitigation Plan for Aquatic Resource Impacts, Museo del Niño, SAJ-2001-03999(SP-CGR).)

\begin{tabular}{|c|c|c|c|}
\hline Scientific name & Common name & $\begin{array}{l}\text { No. of trees } \\
\text { planted }\end{array}$ & $\begin{array}{l}\text { Mitigation areas/ } \\
\text { planting zone }\end{array}$ \\
\hline $\begin{array}{l}\text { Pterocarpus } \\
\text { officinalis }\end{array}$ & Bloodwood & 976 & $\begin{array}{c}\mathrm{B}, \mathrm{C} ; \text { Wetland } \\
\text { enhancement area and } \\
\text { transitional area }\end{array}$ \\
\hline Annona glabra & Swamp apple & 923 & $\begin{array}{c}\mathrm{B}, \mathrm{C} ; \text { Wetland } \\
\text { enhancement area and } \\
\text { transitional area }\end{array}$ \\
\hline Rhizophora mangle & Red mangrove & 250 & $\begin{array}{c}\mathrm{C} \text {; Wetland enhancement } \\
\text { area, along canal }\end{array}$ \\
\hline $\begin{array}{l}\text { Laguncularia } \\
\text { racemose }\end{array}$ & White mangrove & $\begin{array}{l}\text { Broadcasting } \\
\text { of seedlings }\end{array}$ & $\begin{array}{c}\text { C: Wetland enhancement } \\
\text { area, along canal }\end{array}$ \\
\hline Andira inermis & $\begin{array}{l}\text { Cabbagebark } \\
\text { tree }\end{array}$ & 222 & $\begin{array}{c}\text { A, B; Upland buffer and } \\
\text { transitional area }\end{array}$ \\
\hline $\begin{array}{l}\text { Calophyllum } \\
\text { antillanum }\end{array}$ & $\begin{array}{l}\text { Alexandria } \\
\text { laurel }\end{array}$ & 96 & $\begin{array}{c}\text { A, B; Upland buffer and } \\
\text { transitional area }\end{array}$ \\
\hline Inga laurina & White Inga & 29 & A; Upland buffer \\
\hline $\begin{array}{l}\text { Citharexylum } \\
\text { spinosum }\end{array}$ & Fidlewood & 104 & A; Upland buffer \\
\hline Byrsonimia lucida & Locust berry & 13 & A; Upland buffer \\
\hline Shaefferia frutescens & $\begin{array}{l}\text { Florida- } \\
\text { boxwood }\end{array}$ & 7 & A; Upland buffer \\
\hline Guarea guidonia & Rusby & 16 & A; Upland buffer \\
\hline $\begin{array}{l}\text { Garcinia } \\
\text { portoricensis }\end{array}$ & Palo de cruz & 5 & A; Upland buffer \\
\hline Stahlia monosperma & Cobana negra & 47 & $\begin{array}{c}\text { A, B; Upland buffer and } \\
\text { transitional area }\end{array}$ \\
\hline \multirow[t]{2}{*}{ Thespesia grandiflora } & Maga tree & 108 & A, Upland buffer \\
\hline & Total & 2796 & \\
\hline
\end{tabular}

2.5 Enhancement of degraded herbaceous wetland (PFO3C)

This method was carried out within Mitigation Area A, and its being implemented also in Mitigation Areas B and C. Approximately 1.8 acres $\left(7367.7 \mathrm{~m}^{2}\right)$ of degraded herbaceous wetlands within Mitigation Area A were enhanced by planting approximately 2,335 wetland tree species. This area was hydrologically connected to the constructed open water canal and was planted with wetland adapted and transitional species such: Swamp apple (Annona glabra) and Bloodwood (Pterocarpus officinalis; (Fig. 4)). In Mitigation Areas B and C, with a total area of approximately 4 acres $\left(16,075.6 \mathrm{~m}^{2}\right), 4,019$ trees will be planted by the end of March 2020. 

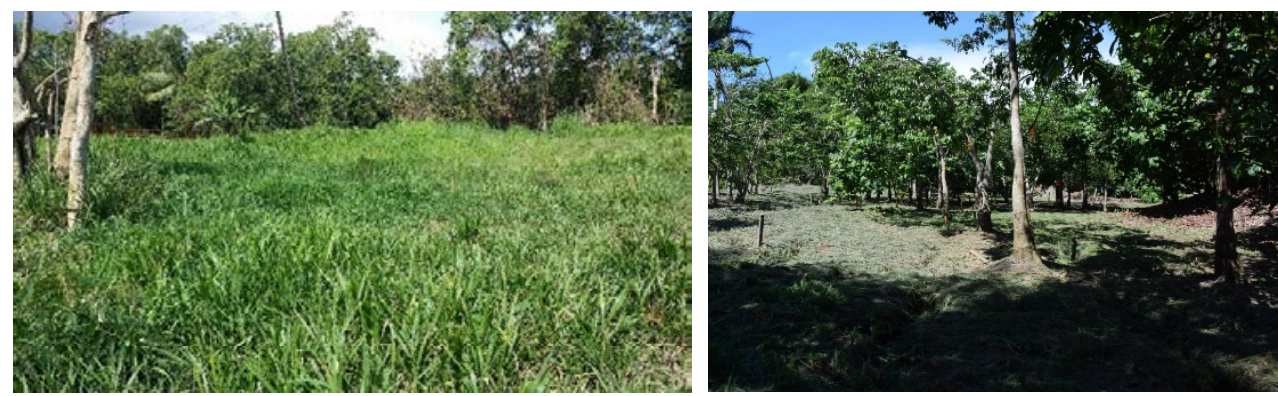

Figure 4: Before and after view of a section of Mitigation Area A with 4.5-year old Bloodwood trees.

\subsection{Establishment of a forested upland buffer zone (UPL)}

A forested upland buffer zone of approximately 0.46 acres $\left(1845.6 \mathrm{~m}^{2}\right)$ was created along the eastern section of the Mitigation Area A. This area was planted with upland and transitional species, such as Cabbage bark (Andira inermis), Alexandria laurel (Calophyllum antillanum), Fiddlewood (Citharexylum spinosum), Sacky sac bean (Inga laurina), Smooth strongback (Bourreria succulenta), and Maga tree (Thespesia grandiflora), among others. Trees were planted at $4 \mathrm{~m}$ from each other to allow for future growth, and a total of 461 trees were planted.

During construction activities, no site grading was necessary, except for the construction of the upland water canal section at Mitigation Area A. Water from the secondary canal reached Mitigation Area A enhanced wetlands through the new canal providing the necessary hydrologic regime for the site. In contrast, Mitigation Areas B and C were near the water table and elevations of existing canals; therefore, the hydrology source already existed within both sites. Once the construction of the canal was completed, the planting plan was developed. The plan relied upon planting selected plant species to establish the plant community, seed bank, natural recruitment, and control or management of undesirable invasive exotic species. Most of the planted species produce fruits or seeds that are important food source to wildlife. This technique assured a higher ecosystem productivity and increase wildlife diversity.

Planting of wetland/upland transitional native trees (canopy species) was proposed at the eastern perimeter of the Mitigation Area A. This planting created a buffer zone between the mitigation site and the nearby urban residential area north of the CMS. An alternate planting arrangement was used to mimic the natural vegetation structure of the local wetland plant community.

As part of the project development, a set of performance standards were proposed. These standards followed the Regulatory Guidance Letter No. 08-03 (minimum monitoring requirements for compensatory mitigation projects involving the restoration, establishment, and/or enhancement of aquatic resources) [7]. The performance standards corresponded to the design objectives and goals, and defined measurable criteria that were evaluated to predict when a mitigation element has been successfully implemented or accomplished and whether overall mitigation goals were met at the end of the monitoring program [9]. Performance standards are measurable criteria that are evaluated at periodic time intervals during monitoring and serve as indicators of the need for adaptive management or contingency actions. 
The established performance standards measure the success of the compensatory mitigation during the monitoring period. Specific standards included: vegetative cover colonization, natural recruitment, and survival performance to assess the success of planted vegetation, and of the natural vegetative colonization. A survival rate of $85 \%$ was set as the standard for our planted trees at all mitigation sites. Also, we established an invasive vegetation standard to determine the percent cover of invasive plant species that invade or colonize the mitigation sites during the monitoring period. No more than $15 \%$ of invasive species is permitted to invade all mitigation areas. Finally, we established a hydrologic performance standard to assess the amount of ground and surface saturation and ponding, and a habitat performance standard to assess the use of restored available habitat by wildlife.

\section{RESULTS AND DISCUSSION}

The construction activities within Mitigation Area A were completed in early October 2015 and an As Built and Time Zero Monitoring Report was prepared on October 29, 2915. At the beginning of the mitigation effort herbaceous vegetation within Mitigation Area A was 95\% dominated by Mexican crown grass (Paspalum fasciculatum) and 5\% by Mimosa casta (no common name). Although both species are considered native to the Antilles [9], [10] they are intensely invasive. Nevertheless, they have been controlled at this time by the application of herbicide and pruning. No other herbaceous species is present within Mitigation Area A, except for the Giant Leather Fern (Acrostichum danaeifolium), which is a desirable species and is present in saturated or inundated soils within existing forested wetlands. In this paper all preliminary data related to tree survival comes from Mitigation area A. In July 2016 a semiannual monitoring report for Mitigation area A was completed. When comparing the data between the Time-Zero Report to the first semiannual monitoring period a $15 \%$ of tree mortality was found. Later, in December 2016, the annual report was completed. A data comparison between the Time-Zero Report and the December 2016 annual report, reveal a $27 \%$ of tree mortality which represents an increase of $12 \%$ over the last five months. The tree species that showed the highest survival rate at Mitigation area A were: Rizophora mangle, 85.2\%; Citharexylum spinosum, 62.5\%; and Andira inermis, 62.1\%. Across specie, survival rate during the first 13 months of the project of the nine most planted tree species range between $85.2 \%$ to $18.2 \%$ with an average survival rate of $36.1 \%$ (Table 2 ).

Although tree mortality was recorded in all species, we observed an unexpected high mortality in Pterocarpus officinalis, Annona glabra and Calophyllum antillanum. The first two species are known to be adapted to wetland conditions and are relative common in the island wetlands, whereas Calophyllum is a common species planted in roads and ornamental gardens and is tolerant to anthropogenic disturbance [11]. Our findings showed a preliminary $63.9 \%$ of tree mortality which is way above the $15 \%$ maximum tree mortality required by the permit issued by the USACE.

As of March 8,2020, the activities associated with the restoration and mitigation project of the Children Museum have not been completed. After the planting phase was finished in Mitigation Area A and before continuing the preparation of areas B and C, on 20 September 2017 the Island of Puerto Rico was impacted by Hurricane Maria, considered as a major hurricane (winds $>155 \mathrm{mph}$ ). The impact on the Mitigation Area A was significant, destroying an additional $25 \%$ of the trees planted. The municipality resumed the restoration activities on late October with the identification of the surviving trees and clearing the land from dead trees and overgrown grasses. On 3 March 2019 a tree inventory was completed in Mitigation Area A. Of the 2906 trees were initially planted at that area only 997 (36\%) have survived, including wetland, upland and transitional species. Based on field observations, other factors may also have impacted the survival rate of the planted species. During 2015, a 
severe drought affected Puerto Rico, impacting the mitigation site in Carolina. The drought significantly affected both, Pterocarpus and Annona trees. This event last 4 months decimating a vast number of trees. Although the municipality provided water tanks and personnel, the process did not help the planted tress as expected. Also, the extensive use of trimmers for cutting grass as part of the regular maintenance to the parcel by municipality workers, severely damaged dozens of trees planted in the Mitigation Area A. Although these numbers are well below the required survival rate established by the USACE, the remaining trees continue growing as expected while providing food and roost site to wildlife and improving the conditions in the restored wetland area. During a 24-month period more than 30 wildlife species, mostly birds, have been observed foraging or nesting in the Mitigation Area A including: Northern mockingbird (Mimus polyglottos), Puerto Rican woodpecker (Melanerpes portoricensis), Zenaida Dove (Zenaida aurita), White-winged Dove (Zenaida asiatica), Bananaquit (Coereba flaveola), Puerto Rican Spindalis (Spindalis portoricensis) and the Yellow-crowned Night-Heron (Nyctanassa violacea). Additional wildlife observed using the Mitigation area A are several species of Anolis lizards; crustaceans such as the Fidler crab (Uca sp.) and Land blue crab (Cardisoma guanhumi), considered a critical element by the Puerto Rico Department of Natural and Environmental Resources; and a rich diversity of terrestrial invertebrates (e.g., insects and arthropods) that forage or live over the vegetation [12].

Table 2: Percent of survival of the nine most common tree species planted at Mitigation Area A. Preliminary data from October 2015 to December 2016.

\begin{tabular}{|c|c|c|c|}
\hline Tree species & $\begin{array}{c}\text { No. of trees } \\
\text { planted }\end{array}$ & $\begin{array}{c}\text { No. of } \\
\text { surviving trees } \\
\end{array}$ & $\%$ of survival \\
\hline Pterocarpus officinalis & 976 & 178 & 18.2 \\
\hline Annona glabra & 923 & 284 & 30.7 \\
\hline Rhizophora mangle & 250 & 213 & 85.2 \\
\hline Andira inermis & 222 & 138 & 62.1 \\
\hline Thespesia grandiflora & 108 & 59 & 54.6 \\
\hline Citharexylum spinosum & 104 & 65 & 62.5 \\
\hline Calophyllum antillanum & 96 & 32 & 33.3 \\
\hline Stahlia monosperma & 47 & 13 & 27.6 \\
\hline Inga laurina & 29 & 15 & 51.7 \\
\hline Total & 2755 & 997 & 36.1 \\
\hline
\end{tabular}

Maintenance and preparation of all mitigation areas continued during 2018 and 2019. Planting of mitigation areas B and C continued during the month of January 2020 with the planting of 249 trees in area B. The species planted included Bloodwood (Pterocarpus officinalis), Swamp apple (Annona glabra) and Alexandria laurel (Calophyllum antillanum). To maintain the required $85 \%$ survival rate at the Mitigation Area A, approximately 2500 additional trees will be planted. For the Mitigation Areas B and C, the following species are being planted: 1000 Bloodwood (Pterocarpus officinalis), 400 Alexandria laurel (Calophyllum antillanum), 400 Green bottonwood (Conocarpus erectus), 400 Middle-aged Black-Calabash (Amphitecna latifolia), and 75 Puerto Rican royal palm (Roystonea borinquena). 


\section{CONCLUSIONS}

When comparing the data between the Time-Zero Report to the December 2016 annual monitoring, 39\% of trees planted increased their height, so that tree diameter could be measured at breast height $(\mathrm{DBH})$, and not at $10 \mathrm{~cm}$ from soil surface. Average DBH by species was 4 inches. Average tree height increased from $1.32 \mathrm{~m}$ to $2.34 \mathrm{~m}$ between the Time-Zero monitoring event to this end of year monitoring event. This represents an increase of $44 \%$ in tree height. DBH also increased $46 \%$ between these two events. These are partial results as the construction of the wetland restoration and mitigation project in the area of the Children's Museum will continue until the end of April 2020. The remaining sowings will be carried out in the areas of Mitigation B and C and they will replace more than 2000 trees in the area of Mitigation A that were lost since the beginning of the project in 2015 . Experience has shown that the planning and preparation of a restoration proposal must be carefully analyzed to establish the appropriate variables, understand the existing soil conditions and select suitable species that allow a higher survival rate. During the planning and conceptualization of a wetland restoration project, the risks and probabilities of success in reforesting a particular area should be carefully analyzed with the intention of returning the property to its original state. The functions and type of wetland must be reflected in the planning documents in order to develop a successful concept [9]. The data collected during the construction and maintenance of this project, will be utilized in improving the remaining construction activities. Based on the field observations, the parcel north of the Children Museum is functioning as a viable wetland. The level of recovery and functionality is subject to debate. It will be critical to collect additional data associated with the vegetation, hydrology and fauna communities to corroborate any predictions of wetland function.

\section{ACKNOWLEDGEMENTS}

The authors would like to appreciate the City of Carolina, staffers from the Legal, Project Management and Public Works Offices, and their Mayor José Aponte Dalmau, for their continuous support during the planning and construction of this project.

\section{REFERENCES}

[1] Mitsch, W.J. \& Gosselink, J.G., Wetlands, John Wiley \& Sons: New York, 2007.

[2] Environmental Protection Agency. https://www.epa.gov/cwa-404/permit-programunder-cwa-section-404. Accessed on: 6 Mar. 2020.

[3] Cowardin, L.M., Carter, V., Golet, F.C. \& LaRoe, E.T., Classification of Wetlands and Deepwater Habitats of the United States, U.S. Department of Interior, Fish and Wildlife Service: Washington, D.C., 1979.

[4] Tyner, R.W., Wetland Indicators: A Guide to Wetland Identification, Delineation, Classification and Mapping, CRC Press LLC: Boca Raton, 1999.

[5] EcoStahlia Consultores Ambientales, LLC and Coll Rivera Environmental Services. Compensatory Mitigation Plan (CMP), 2014.

[6] Federal Register. Compensatory Mitigation for Losses of Aquatic Resources. https://www.federalregister.gov/documents/2008/04/10/E8-6918/compensatorymitigation-for-losses-of-aquatic-resources. Accessed on: 3 Mar. 2020.

[7] US Army Corps of Engineers. Regualtory Guidance Letter. https://www.epa.gov/sites/production/files/2015-08/documents/mitigation_rgl_022 0.pdf. Accessed on: 24 Feb. 2020.

[8] United States Department of Agriculture. Welcome to Web Soil Survey. https://websoilsurvey.sc.egov.usda.gov/App/HomePage.htm. Accessed on: 25 Feb. 2020. 
[9] National Academies Press. Compensating for Wetlan Losses Under the Clean Water Act. https://www.nap.edu/read/10134/chapter/1. Accessed on: 25 Feb. 2020.

[10] Axelrod, F.S., A Systematic Vademecum to the Vascular Plants of Puerto Rico. Botanical Research Institute, Texas: Fort Worth, 2011.

[11] Feagin, R.A., Toledo-Rodríguez, F., Colón-Rivera, R.J., Smeins, F. \& Lopez, R., Species Composition and Differences in Diversity Among the Pterocarpus officinalis Forested Wetlands of Puerto Rico. The Caribbean Naturalist, 4, 2013.

[12] DRNA. Reglamento de Pesca de Puerto Rico - 2010. http://www.drna.pr.gov/documentos/reglamento-num-7949/. Accessed on: 8 Mar. 2020. 